\title{
Cryptobarsac rubriops, a new genus and species of selizine Flatidae (Hemiptera: Fulgoromorpha) from grasstrees (Xanthorrhoea preissii) in south Western Australia
}

\author{
Murray J. Fletcher ${ }^{1}$ and Melinda L. Moir ${ }^{2}$ \\ 'Orange Agricultural Institute, NSW Agriculture, Forest Road, Orange, \\ New South Wales 2800, Australia \\ ${ }^{2}$ Dept of Environmental Biology, Curtin University of Technology, \\ GPO Box U1987, Perth, Western Australia 6845, Australia
}

\begin{abstract}
Cryptobarsac rubriops gen. et sp. nov. (Hemiptera: Fulgoroidea: Flatidae) is described from grasstrees, Xanthorrhoea preissii, in southwestern Western Australia. The genus is placed in the Tribe Selizini. The taxonomy, zoogeography and plant associations of the Australian Selizini are discussed.
\end{abstract}

\section{INTRODUCTION}

The Australian Flatidae (Hemiptera: Fulgoromorpha) were reviewed by Fletcher (1988) who provided descriptions of 22 genera and a key for their separation. An electronic version of this key was published by Fletcher and Larivière $(2001+)$. More than half of the genera are endemic and associated with the sclerophyllic flora that dominates most of the continent. Work by Medler $(1986,1990,2000)$ has updated the generic identities of the Flatidae of Australia and neighbouring areas, particularly New Guinea, and these changes have been incorporated into Fletcher and Larivière $(2001+)$.

Research by the second author has focussed on the hemipterous fauna of selected species of native sclerophyllic plants in regenerating bauxite mine pits and surrounding Jarrah (Eucalyptus marginata Smith) forest in SW Western Australia. Such intensively targeted collecting has found a number of species of unusual Hemiptera and one of these is described below as Cryptobarsac rubriops gen. and $s p$. nov. from Xanthorrhoea preissii Endl. (Xanthorrhoeaceae).

Abbreviations: ASCU, NSW Agricultural Scientific Collections Unit; WADA, Western Australian Department of Agriculture; WAM, Western Australian Museum.

\section{Cryptobarsac gen. nov.}

Type species: Cryptobarsac rubriops sp. nov.

\section{Diagnosis}

Habitus, from lateral aspect, as in Figure 1. Head short, with frons (Figure 2) broader than long, convex bearing median longitudinal carina and semicircular carina reaching to lower level of eyes on each side and fused to percurrent apical marginal carina over median third. Vertex (Figure 3 ) very short, concave behind elevated anterior marginal carina. Pronotum (Figure 3 ) broadly rounded anteriorly, front margin reaching to anterior margin of eyes, carinate, extending laterally to almost meet hind margin, which is strongly and evenly concave. Dorsal pronotal surface flattish behind anterior curved carina, raised along median line on posterior half. Postocular prominences reduced in height but extended dorsoventrally. Mesonotum (Figure 3) broader than long, without median carina, lateral carinae well developed, posterior ends closer together than anterior. Tegmina (Figure 1) narrow, parallel-sided, evenly rounded posteriorly, angles not distinguished, outwardly prominent along basal portion of $\mathrm{R}$. One subapical line present. Costal membrane as wide as costal cell then widening beyond apex of cell. R, M and $\mathrm{Cu}$ originating in basal cell, Rs separating some distance from base, $\mathrm{Cu}$ simple or branched before midlength. Hind tibia with two spines.

\section{Etymology}

The generic name, which is feminine, reflects the cryptic microhabitat in which the type species was found and the superficial similarity of the species to members of the genus Barsac Fletcher which occurs in drier habitats of Australia.

\section{Notes}

In the key provided by Fletcher (1988) this genus keys to couplet 4 on the basis of two hind tibial spines. It can be distinguished from Mimophantia Matsumura by having the head not extended in front of the eyes to form an extensive vertex and from Anzora by the presence of a clear percurrent 
carina defining the anterior margin of the vertex and separating it from the frons. The key provided by Fletcher and Larivière $(2001+)$ has been updated to include Cryptobarsac.

The short head, brown coloration and narrow parallel-sided tegmina outwardly prominent near the base of R (Medler, 1990, uses the term "bulla" for this feature) place Cryptobarsac in the tribe Selizini of the Subfamily Flatinae as defined by Melichar (1923).

\section{Cryptobarsac rubriops sp. nov.}

(Figures 1-6)

\section{Types}

\section{Holotype}

Male, Jarrahdale, SE of Perth, WA, beating Xanthorrhoea preissii in jarrah forest, 10 December 2000, M. Fletcher and M. Moir (WAM)
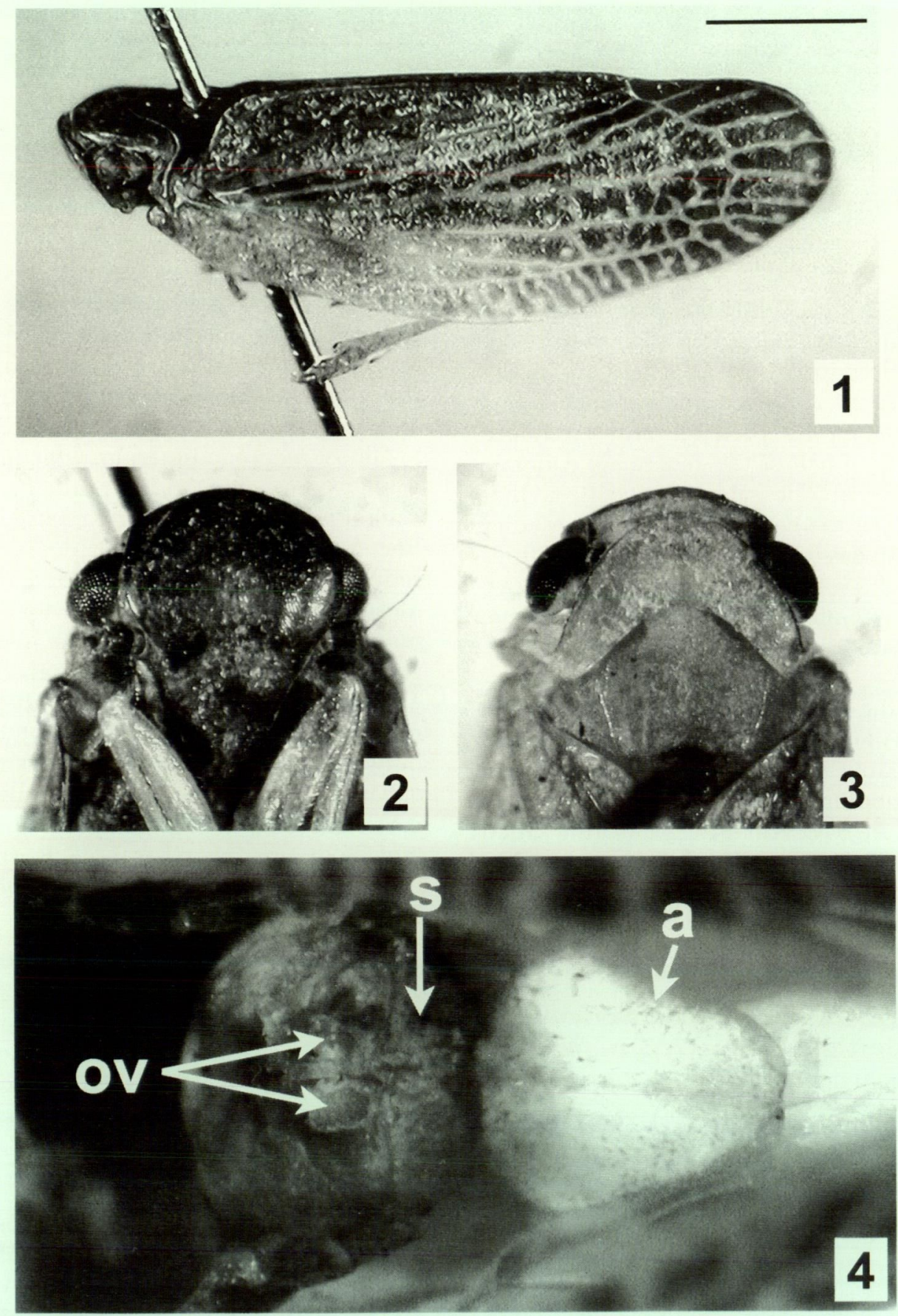

Figures 1-4 Cryptobarsac rubriops gen. et sp. nov.: 1, adult, habitus; 2, adult, facial view of head; 3, adult, dorsum; 4 , female genitalia, ventral view, a: anal segment, s: secretory area, ov: ovipositor valves. Scale line: $1 \mathrm{~mm}$ 


\section{Paratypes}

5 males, 5 females, Jarrahdale, WA $32^{\circ} 66^{\circ} 49^{\prime \prime} \mathrm{S}$ $116^{\circ} 10^{\prime} 12^{\prime \prime} \mathrm{E}$, tree beating, Xanthorrhoea preissii, November 2001, Melinda Moir (2 males, 2 females: ASCU; 2 males, 2 females: WAM; 1 male, 1 female: WADA)

\section{Description}

Small, length (in midline from apex of head to tip of tegmen): males $(\mathrm{n}=6) 5.12 \pm 0.22 \mathrm{~mm}$, females $(\mathrm{n}=5) 5.47 \pm 0.12 \mathrm{~mm}$, brown, paler ventrally and on veins of tegmen, dark brown in cells. Some specimens pale brown on head and thorax with base of tegmen pallid. Eyes dark red in living specimens fading to dark reddish brown when dead. Male genitalia: pygofer (Figure 5) short, lacking process at posterodorsal corner which bears line of short setae. Subgenital plates (Figure 5) convex on basal half, apically truncate with well developed dorsal process straight and in line with apical truncation of plate. Anal segment long and broad with line of 3-4 short marginal setae slightly beyond midlength. Aedeagus as in Figure 6, with single pair of recurved processes on phallosoma. Female, with ovipositor valves reduced to paired ovate lobes. Posterodorsal section of pygofer flattened, bearing pad of dense packed setae, opposed to broadly expanded ninth (anal) segment held horizontally and at least $2 / 3$ length of remainder of abdomen together (Figure 4).

\section{Etymology}

The specific name refers to the dark red eyes.

\section{Notes}

With other flatid genera, the male genitalia provide the most useful attributes for distinguishing between species. With only the single species known, it is presumed that the structure of the aedeagus (Figure 6) will provide diagnostic features of this species. The lack of a process on the posterodorsal corner of the pygofer and the presence of a strong process on the subgenital plates (Figure 5) may be generic features as also may be the strongly expanded anal segment of the female.

\section{DISCUSSION}

\section{Taxonomy}

Melichar (1923) provided keys to genera of the world Flatidae and included a number of Australian genera in the Tribe Selizini. These were Massila Walker, Dascalina Melichar, Jamella Kirkaldy and Uxantis Stål. Modifications to Melichar's (1923) generic arrangements were made by Metcalf (1957), who transferred Uxantis to the subfamily Flatoidinae, and Medler (1990), who transferred
Jamella, also to the Flatoidinae. New genera of Australian Selizini were added by Fletcher (1988) and, with the addition of the current new genus, the Australian Selizini now includes the five genera Massila with four species, Dascalina with four species, Barsac Fletcher with four species and the monotypic genera Austrodascalia Fletcher and Cryptobarsac gen. nov. All Australian Selizini are endemic at the generic level.

Of these genera, only Barsac and Cryptobarsac have a subapical line of crossveins. The general shape of the head and tegmina are similar between the species in the two genera as well. However, the four species of Barsac have similarities in the structures of the genitalia, which are quite different from the genitalia structures of C. rubriops. These include the subgenital plate being convex with outwardly curving dorsal process and the presence of two pairs of aedeagal processes one of which is mounted apically. In C. rubriops the subgenital plate is triangular with a straight dorsal process that does not curve outwards and the aedeagus has a single pair of non-apical processes.

In the key offered by Melichar (1923), Cryptobarsac keys to Dascalina, from which it differs in the shape of the tegmen, the apical margin being concave in Dascalina, and in the shape of the head, which is extended forward a short distance so that the frons curves ventrally to become almost horizontal in
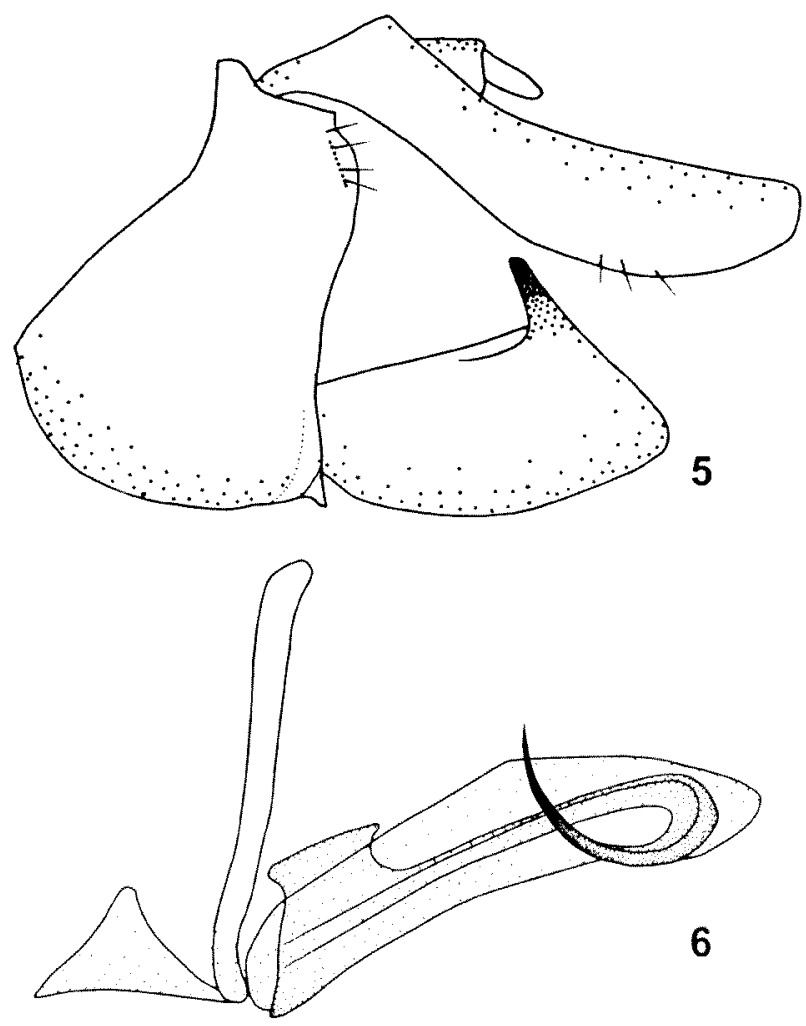

Figures 5-6 Cryptobarsac rubriops gen. et. sp. nov: 5 , male terminalia, lateral view; 6 , aedeagus, lateral view. 
Dascalina. Cryptobarsac also differs from all other Australian Selizini in having two spines rather than one on the hind tibia. In Australia, only Anzora unicolor (Walker) (Tribe Nephesini, Subtribe Cryptoflatina) and Mimophantia stictica (Melichar), which was moved from the Tribe Phyllyphantini to the Tribe Phantiini by Medler (1988), have two spines on the hind tibia.

\section{Biology}

Fletcher (1979) provided details of the ovipositor and egg laying strategies of some species of Flatidae, many of which glue rafts of eggs onto leaf surfaces while others insert them into plant tissue. Anzora unicolor has a well developed sclerotised ovipositor bearing marginal teeth which is clearly capable of penetrating plant tissue while with other species the ovipositor is reduced to small lobes used for manipulating eggs into a surface raft. The Australian species of Selizini, including $C$. rubriops, have the reduced type of ovipositor consisting of small rounded lobes that would be incapable of cutting plant tissue. An expanded anal segment such as is found in C. rubriops (Figure 4) is also found in Massila and Dascalina and is presumably used either to help shape the egg mass or to spread a protective covering of wax over the eggs as was described in Siphanta acuta (Walker) by Muir and Kershaw (1912). Even in old pinned specimens, the anal segment usually still carries quantities of waxy filaments. These species presumably lay an egg mass similar to those laid by Siphanta species with the wax produced from the secretory area and manipulated by the large anal lobe. The degree of expansion of the anal segment found in female $C$. rubriops and species of Massila is greater than that found in species in other genera.

\section{Habitat and plant associations}

The Australian Selizini are frequently distributed in the more arid areas of the continent. Barsac species are found in inland areas of Western Australia, South Australia and Queensland. Austrodascalia evansorum Fletcher was described from Einasleigh River, a remote inland town in North Queensland, which has a monsoonal climate with extended periods of drought. Dascalina is distributed in similar monsoonal areas across northern Australia from Western Australia to Queensland. Cryptobarsac is described above from the northern Jarrah forest at Jarrahdale, $50 \mathrm{~km}$ SE of Perth in Western Australia. This is an area of highly leached, nutrient deficient lateritic soils, with rainfall (1100 - $1300 \mathrm{~mm}$ per annum) confined mainly in the period from May to July (Ward et al. 1996). Massila species are distributed along the eastern coastal areas of Queensland with $M$. sicca
Walker extending into New South Wales as far south as Sydney.

Species of Massila are commonly found on exotic garden plants in coastal districts of eastern Australia but host associations are poorly known for most of the Australian Selizini. The only host records known prior to this current work is a paratype of Barsac cocoa Fletcher collected from foliage of Eucalyptus gamophylla F.Muell. (Myrtaceae) near Mt Bruce in the Pilbara district of Western Australia and the type series of Austrodascalia evansorum Fletcher collected from Melaleuca sp. (Myrtaceae) at Einasleigh River in North Queensland. E. gamophylla is a eucalypt species that grows as a mallee in deep sandy soils in arid regions of Western Australia, South Australia and the Northern Territory. Melaleuca is a genus of more than 200 species ranging from small shrubs to huge trees scattered across a wide range of habitats in Australia (Craven \& Lepschi 1999). The most common species of the genus found in the Einasleigh River region of Queensland is $M$. viridiflora Gaertner (J.F. Donaldson, pers. comm. 2002).

The known specimens of $C$. rubriops were all collected by beating the "skirt" of dead leaves that normally adorn the upper parts of the trunk of $X$. preissii. The insects hide deep inside the skirt close to the main stem. Their narrow shape presumably helps them to move within the leaves of the grasstree where the dull brown coloration may provide further protection from detection. It is unknown whether they move out onto the living leaves to feed at night or whether they gain nourishment by feeding at the bases of the leaves under the skirt.

Mallee growth habits provide a microhabitat towards the base of the multiple trunks where bark and dead leaves accumulate providing protection for insects similar to that provided by the hanging skirt of dead leaves around the stem of $X$. preissii. However, any generalisation about microhabitats preferred by the species of Selizini found in Australia would be speculative without considerable further host data.

\section{ACKNOWLEDGEMENTS}

The authors acknowledge support from Alcoa World Alumina Australia and Curtin University of Technology for funding collection of specimens, Jonathan D. Majer and John M. Koch for their supervision of the second author and Karl E.C. Brennan and Erich S. Volschenk for informative discussions. We also thank John Donaldson, Queensland Dept of Primary Industries, Indooroopilly for the provision of habitat information on the type locality of $A$. evansorum. 


\section{REFERENCES}

Craven, L.A. and Lepschi, B.J. (1999). Enumeration of the species and infraspecific taxa of Melaleuca (Myrtaceae) occurring in Australia and Tasmania. Australian Systematic Botany 12: 819-927.

Fletcher, M.J. (1979). Egg types and oviposition behaviour in some fulgoroid leafhoppers (Homoptera, Fulgoroidea). Australian Entomological Magazine 6: 13-18.

Fletcher, M.J. (1988). The Australian genera of Flatidae (Homoptera, Fulgoroidea). General and Applied Entomology 20: 9-32.

Fletcher, M.J. and Larivière, M.-C. (2001 and updates). Identification Keys and Checklists for the leafhoppers, planthoppers and their relatives occurring in Australia and New Zealand (Hemiptera: Auchenorrhyncha). http://www.agric.nsw.gov.au/Hort/ ascu/start.htm

Medler, J.T. (1986). Anzora and Dworena, two new genera erected for Australian species formerly placed in Paratella and Sephena (Homoptera: Flatidae). Insecta Mundi 1: 206-208.

Medler, J.T. (1988). Revisional notes on classification of the tribe Flatini (Homoptera, Auchenorrhyncha,
Flatidae). Proceedings of the 6th Auchenorrhyncha Meeting, Turin, Italy, 7-11 Sept 1987: 59-63.

Medler, J.T. (1990). Review of Jamella Kirkaldy and Malleja, gen. nov. in Australia and New Guinea, with descriptions of new species (Homoptera: Flatidae). Invertebrate Taxonomy 3: 995-1004.

Medler, J.T. (2000). Flatidae of New Guinea and Adjacent Areas (Homoptera: Fulgoroidea). Bishop Museum Bulletins in Entomology 8: 1-117.

Melichar, L. (1923). Homoptera. Fam. Acanaloniidae, Flatidae et Ricaniidae. Genera Insectorum 182: 1-185.

Metcalf, Z.P. (1957). General Catalogue of the Homoptera. Fascicle IV Fulgoroidea. Part 13 Flatidae and Hypochthonellidae. North Carolina State College, Raleigh, NC, USA. 565pp.

Muir, F. and Kershaw, J.C. (1912). The developments of the mouthparts in the Homoptera, with observations on the embryo of Siphanta. Psyche 19: 77-89.

Ward, S.C., Koch, J.M. and Ainsworth, G.L. (1996). The effect of timing of rehabilitation procedures on the establishment of a Jarrah forest after bauxite mining. Restoration Ecology 4: 19-24.

Manuscript received 13 March 2002; accepted 24 April 2002 